\title{
Socio-economic factors influencing rice production among male and female farmers in Northern Guinea Savanna Nigeria: lessons for promoting gender equity in action research
}

\author{
Ayoola $^{1}$, J. B.; C. Dangbegnon ${ }^{2}$, C.K. Daudu ${ }^{3}$ A. Mando ${ }^{2}$, T.M. Kudi', I.Y. Amapu ${ }^{4}$, J.O. \\ Adeosun $^{3}$, and K.S. Ezui ${ }^{2}$ \\ ${ }^{1}$ Cooperative Extension Center, University of Agriculture, Makurdi, Nigeria \\ ${ }^{2}$ An International Center for Soil Fertility and Agricultural Development (IFDC) \\ ${ }^{3}$ National Agricultural Extension and Research Liaison Services (NAERLS), (ABU), Zaria, \\ Nigeria \\ ${ }^{4}$ Institute of Agricultural Research (IAR), Ahmadu Bello University (ABU), Zaria, Nigeria
}

\begin{abstract}
This paper examined the performance of male and female farmers in rice farming in the Northern Guinea Savannah of Nigeria, with a view to determining the parameters for promoting gender equity in farmers' access to opportunities for improved livelihoods from rice production. Data were obtained from 624 farmers selected by stratified random technique from twelve villages in Katsina and Kaduna States of Nigeria; using structured interview and focus group discussion. The data were analyzed using descriptive statistics and regression model of double log form. Results indicated that land, variable inputs, and experience were significant at 1 percent and 5 percent levels; implying that these variables would greatly influence productivity of rice for both male and female farmers in the area; while age would influence rice production negatively, implying that the older the rice farmers the less the vigour for farming. Also, the coefficient for marital status of women was negative; implying that married women within reproductive age were more likely to be constrained in their production by their multiple roles and cultural practices that prevented women from direct field production activities. It was concluded that policies that would enhance farmers access to land, fertilizers, improved seeds, herbicides and labour; coupled with strategies for substituting women's time on production activities for non-entrepreneurial activities would likely enhance rice production and gender equity among rice farmers in the Northern Guinea Savanna, Nigeria.
\end{abstract}

Key words: Rice production, gender equity, Northern Guinea Savanna, Nigeria

\section{INTRODUCTION}

Agriculture accounts for over 70 percent of the active labor force, and more than 23 percent of the Gross Domestic Product in Nigeria (World Bank, 2007). Agriculture is the mainstay of the majority of Nigerian rural poor, producing major food crops comprising cereals such as sorghum, maize, rice; tubers such as yams, cassava, legume such as groundnut and cowpea as well as vegetables. Nigeria is the most populous country in Africa, with a population of over 40 million people (NPOC, 2006); the larger part of which is poor and food insecure, with women and children mostly affected. The food produced, mostly at subsistent level is inadequate due to low crop yield. FAO (1999) observed that the average crop yields for the Africa region have remained low over the last decade; while increases in food production have been achieved largely through extending the area under cultivation rather than productivityimproving technologies. Thus the food produced has not been able to sustain access of all people at all times, to adequate food and nutrition for a active and healthy life, in most parts of African region. According to the World Bank (1996), poverty is hunger, among other indicators; and Nigeria with Human Poverty Index value of 37.3 , ranked among the poorest countries in the world (UNDP, 2005).

Rice is a major staple food in Nigeria, but its domestic production has never been able to meet the demand; FAO $(1999,2006)$ and Erenstein et al. (2003) observed that the demand and supply gap in rice production is widening, resulting in huge import 
bill on rice. The National Special Programmes on Food Security (NSPFS) and the Presidential Initiative on rice, aimed at attaining food sufficiency in local production of rice in the short term (2005) and increased export in the medium term (2007), with targets of 3 million hectare cultivation, and 15 million tons of paddy rice or 9 million metric tons of milled rice (FMAWR, 2008). Despite these efforts, Nigeria is still the world's largest importer of rice (FAO, 2006)

Women play vital roles in food production, processing and marketing in Nigeria; producing about $60-80$ percent of food in the country (Buckland and Haleegoah, 1996; Rahman et al 2004), and contributing about 60-80 percent of agricultural labour force (Mgbada, 2000). They also contribute to household well being through their income generating activities (Ayoola, 1999; Rahman and Usman, 2004). Despite the immense contributions of women to agriculture, various findings have reported that women farmers generally, and particularly in Nigeria, lack access to adequate productive resources such as land, credit, agricultural inputs, education, extension services, and appropriate technology, due to various socio-economic factors (Rahman, 2008). Thus, gender has become a critical cross-cutting factor in innovation process to promote equity and enhance the relative access of female and male farmers to necessary resources in programmes targeted at promoting household food security and poverty reduction. However, the gender roles and relative performance of male and female farmers in the production of rice in the Northern Guinea Savanna of Nigeria have not been adequately valued by research and documentation. It therefore was necessary to assess the existing gender roles and resource distribution among rice farmers in the Northern Guinea Savannah of Nigeria; to establish benchmark for developing strategy for promoting gender equity in the innovation process involving rice farmers in the area. The hypothetical question is whether the socio-economic factors of male and female farmers have significant influence on their rice outputs. The general objective was to assess the entrepreneurship of men and women in rice production; and specifically, to determine the socioeconomic factors influencing rice production, and estimate the parameters of the key inputs for rice production for men and women in the Northern Guinea Savanna of Nigeria.

\section{METHODOLOGY}

The study was conducted in Katsina and Kaduna States in the Northern Guinea Savanna of Nigeria; where primary data were obtained from a total of 624 farmers (264 male and 360 female). The sample was selected by stratified random techniques from identified groups of male and female rice farmers and rice processors in twelve villages; four villages in each of Dandume, Kudan and Ikara Local Government Areas. The method of data collection included focus group discussion involving 17 male and 25 female farmers from each of the 12 villages; and individual interview of 10 farmers ( 5 female and 5 male) randomly selected from each focus group in each of community.

The data were analyzed using descriptive and inferential statistics. The descriptive statistics used to summarize the socio-economic characteristics of the farmers were frequency distribution, means and percentage,; while regression model of double log form was used to estimate factors and determinants of rice production for male and female farmers in the study area.

\section{Analytical Model}

The regression model is expressed implicitly as:

$$
Z_{4}=\beta_{0}+\beta X_{1}+\beta_{2} X_{2}+\beta_{3} X_{3}+\beta_{4} X_{4}+\beta_{5} X_{5}+\beta_{6} X_{6}+\beta_{7} X_{7}+\beta_{8} X_{8}+\beta_{3} X_{9+}
$$

E

Where

$Z_{i}=$ quantity of rice produced $(\mathrm{kg})$

$\beta_{o}=$ Constant term

$\beta_{k}=$ Coefficient to be estimated

$\mathrm{X}_{1}=$ age of rice farmers (years)

$\mathrm{X}_{2}=$ farming experience (years)

$\mathrm{X}_{3}=$ level of education measured by the number of years spent in formal school

$\mathrm{X}_{4}=$ land cultivated (ha)

$\mathrm{X}_{5}=$ marital status

$\mathrm{X}_{6}=$ level of productive inputs, measured by the amount (A) spent on all variable inputs including labour, fertilizers, improved seeds and herbicides.

$\mathrm{U}=$ independent error term.

\section{RESULTS AND DISCUSSION}

Socio-economic characteristics of respondents: Results on Table1 indicate that majority of the 
respondents were married (about 99 percent and 95 percent respectively for male and female farmers). Results also indicate that both categories of respondents were in their productive age, and the women in their active reproductive years; compared with Kebbeh et al. (2003), which found that an average age of 47 years for farmers in Kaduna and Niger States of Nigeria. These results imply that majority of the women have multiple roles, which are likely to hinder their effective participation in rice production activities; Ezumah et al. (1995) and Ayoola (1999) found that reproduction and domestic responsibilities impinge on women's time and mobility. Literacy level was generally low among the respondents, about 32 percent of the men and less than fifty percent of the women having formal education; compared with a previous finding that about 29 percent of rice farmers in Kaduna and Niger State of Nigeria did not have formal education (Kebbeh et al., 2003). These results indicate that women might not have less understanding of improved technologies about rice production than the male farmers, provided they are equally exposed to such technologies. Greater percentage of the female respondents was involved in community-based associations, about 90 percent and 57 percent respectively for female and male farmers (Table1); indicating that greater proportion of female farmers could be reached through their associations for possible engagement in rice innovation process. Both male and female farmers have long years of experience in farming activities, averaging about 25 years and 21 years respectively; conforming with Kebbeh et al. (2003), which found an average of 21 years of farmers' experience in rice farming in Kaduna and Niger States of Nigeria.. The average farm size of the male respondents was higher than that of the women, probably due to the cultural land tenure that gives the heritage and control of land to men in most parts of the region; Ajani (2008) reported that patriarchal structures and authorities give more resources to men in Nigeria, resulting in women having less access to productive resources, particularly land, which is perhaps the most economic constraint for most rural women. It was also found that the women utilize less of agricultural inputs including fertilizers, herbicides and labour than the male farmers. The average output of rice by male farmers was about $4655 \mathrm{~kg}$ while that of female farmers was about $3293 \mathrm{~kg}$, compared with the findings of Singh et al (1997) of an average yield of 1.8tons paddy/ha and 4.6 tons per year. The lower outputs of rice from women's farms could be explained by the relatively less quantities of input use by the female farmers. Akpokodje et al (2001) proposed the need for increased productivity in order to enhance competitiveness of rice in Nigeria.

Table 2 presents the results of multiple regression of the double log form testing the effects of socioeconomic variables: age $\left(X_{1}\right)$, farming experience $\left(X_{2}\right)$, educational level $\left(X_{3}\right)$, land $\left(X_{4}\right)$, marital status $\left(X_{5}\right)$, and total variable cost $\left(X_{6}\right)$ on rice production by male and female farmers. The coefficient of determination indicated that 89.6 percent of the total variation in rice production by men was explained by the estimated variables and 77.8 percent in the case of the women. Among all the explanatory variables, land, level of variable inputs used, experience and age were significant implying that these variables would greatly influence productivity of rice among the male farmers in the area. While age would influence rice production negatively, implying that the older the rice farmers the less the vigour for farming; all the other variables influence rice production positively implying that rice production could be increased by increasing the use of land and variable inputs such as fertilizers, herbicides and labour. While results indicated generally low level of inputs' use, the level of inputs used by female farmers was generally less than that of the male farmers (Table1); similar finding was reported by Ezedinma (2001). Results also showed that all the variables influenced women's output positively except marital status; indicating that marital responsibilities with the associated cultural and religious practices of seclusion that prevented women from out-door direct field production activities, particularly for women within reproductive age; would most likely constrain their participation in rice production. Amaza et al. (1999) attributed women's low access to farm resources to marital and religious reasons. Strategies that mobilize women to get involved in developing innovations that enhance their access to productive resources might increase their productivity in rice production. Previously, Ayoola et al (2006) also opined that policies that encourage the release of women's time from non-entrepreneurial works would likely enhance the productivity of women's time and thus increase the supply of women entrepreneurship in low income households. 
Table1: Socio-economic characteristics of respondents

\begin{tabular}{|l|l|l|}
\hline Variables & Distribution of Respondents by Gender \\
\hline & Male & Female \\
\hline Age (years) & 43.70 & 39.96 \\
\hline Experience (years) & 24.75 & 19.23 \\
\hline Education (\%) & $(44.2)$ & $(45.3)$ \\
\hline Marital Status (\%) & $(97.4)$ & $(98.1)$ \\
\hline Farm size (hectare) & 2.00 & 1.39 \\
\hline Group membership (\%) & $(57.24)$ & $(84.53)$ \\
\hline Fertilizer (bags) & 34.04 & 11.62 \\
\hline Herbicides (litres) & 6.17 & 4.06 \\
\hline Labour (mandays) & 77.28 & 41.76 \\
\hline Rice outputs (kg) & 4655 & 3192 \\
\hline
\end{tabular}

Source: Field Survey, Northern Guinea Savanna, Nigeria, 2009

Note: Percent figures in parenthesis ()

Table3. Results of Regression by Gender

\begin{tabular}{|c|c|c|c|c|}
\hline Model & Male respon & & Female resp & \\
\hline & Coefficients & t-statistics & Coefficients & t-statistics \\
\hline (Constant) & 3.518 & .848 & -9.884 & -1.052 \\
\hline Age (years) & -.141 & -1.296 & .288 & 1.508 \\
\hline Experience (years) & .135 & $1.675^{\star}$ & .265 & 1.487 \\
\hline Educational level & .587 & .487 & 7.290 & $2.799 *$ \\
\hline Land area (ha) & 19.636 & $14.895^{\star \star}$ & 17.421 & $13.570^{\star \star}$ \\
\hline Marital status & -.717 & -.474 & -6.429 & -1.464 \\
\hline Variable productive inputs ( $\#)$ & $5.422 \mathrm{E}-5$ & $2.796^{\star}$ & $6.274 \mathrm{E}-6$ & $1.661^{*}$ \\
\hline
\end{tabular}

Source: Field Survey, Northern Guinea Savanna, Nigeria, 2009

Note: significant at 5 percent level ${ }^{\star *} ; 10$ percent level*

\section{SUMMARY AND CONCLUSION:}

The paper examined the performance of male and female farmers in rice farming in the Northern Guinea Savannah of Nigeria, with a view to determining the parameters for reducing gender imbalance in farmers' access to opportunities for improved livelihoods from rice production. The results of the regression analysis for male farmers showed that land, level of variable inputs (fertilizers, seeds, herbicides and labour), and farmers' experience were significant; implying that these variables would likely influence productivity of rice among the male farmers in the area. Age would influence rice production negatively, implying that the older the rice farmers the less the vigour for farming. Hence, it was concluded that policies that would enhance farmers' access to relevant inputs including land, fertilizers, improved seeds, herbicides and labour would encourage greater production of rice in the area, thereby enabling them to earn more income and improve their livelihoods. The results showed that the coefficient for marital status of women was negative, implying that married women within reproductive age were more likely to be constrained in their production by their multiple roles and cultural practices that prevented women from direct field production activities. Therefore, with particular reference to female rice farmers, it was concluded that policies that would disengage some of women's time from domestic nonentrepreneurial activities to be engaged in more production activities would likely enhance their performance in rice production and create opportunities for increasing their income from rice production.

\section{ACKNOWLEDGEMENT}

The authors hereby expressed their gratitude and appreciation for the funding of this study by FARA, the Forum for Agricultural Research in Africa, through the KKM-Project of the Sub-Saharan Africa Challenge Program. They also recognised the 
important roles played by all the stakeholders like International Fertilizer Development Centre (IFDC), lead institute of the Northern Guinea Savanna of KKM Project), IAR (Institute for Agricultural Research), NAERLS (National Agricultural Extension Research Liaison Services), Cooperative Extension Centre of University of Agriculture Makurdi (CEC/UAM),Dandume Local Government, KATARDA (Katsina State Agricultural and Rural development Authourity), and especially the farmers for the achievement of the goal of this study.

\section{REFERENCES}

Ajani, O.I. (2008). Gender Dimensions in Agriculture, Poverty, Nutrition and Food Security in Nigeria Nigeria Stratey Support Program (NSSP). IFPRI. Pp 5-7

Akpokodje, G, F. Lançon and O. Erenstein (2001). Nigeria's rice economy: State of the art. Paper presented at the NISER/WARDA Nigerian Rice Economy Stakeholders Workshop, Ibadan, 8-9 November 2001. Bouake: WARDA.

Amaza, P.S.,P.V. Kwagbe, and A.A. Amos (2004). Analysis of women's participation in Agricultural Coopertives: Case study of Borno State, Nigeria. Anals of Borno 15/16, pp 187-196

Ayoola, J.B. (1999). Economic Analysis of Women Entrepreneurship in Low Income Households of Benue State, Nigeria. A PhD Thesis Submitted to Abubarka Tafawa Balewa University, Bauchi, Nigeria, in Partial Fulfilment of PhD Degree, March 1999. Pp 53-55

Ayoola, J.B., S. Kushwaha, and J.O. Olukosi (2006). Supply of Women Entrepreneurship in Low-Income Households of Benue State, Nigeria. Journal of Sustainable Tropical Agricultural Research. Vol. 17, pp 17-18

Buckland, L., and J. Haleegoah (1996). Gender analysis in agricultural production. 11TA Research Guide 58 training Programme of International Institute for Tropical Agriculture (IITA). Ibadan, Nigeria. Pp10-12

Ezedinma, C.I. (2001). Economic evaluation and prospects for double rice crop production in humid forest inland valley ecosystems of South Eastern Nigeria. Tropicultura, 19:161-165 pp.

Ezumah, n.N., and C.M. Di Domenico (1995). Nhancing the Role of Women in Crop Production: A case of Igbo Women in Nigeria. World Development Report, Vol 23(10), pp 1731-1744

FAO (1999). Women in Rice Farming Systems. Focus on Sub-Saharan Africa. Women in Agriculture Organisation of the United Nations, Rome pp19

FAO (2006). (2006).Food and Agriculture Organization Year Book. Food and Agriculture Organisation, Rome, Italy. Pg 79.
FMAWR (2008). Nigeria's National Food Security Programme. Federal Ministry of Agriculture and Water Resources, Abuja, Nigeria. Pp 3\&7

Kebbeh, M. S. Haefele and S.O. Fagade (2003). Challenges and opportunities for improving irrigated rice productivity in Nigeria. Abidjan: WARDA.

Mgbada, J.U. (2000). Production of staple crops by rural women in Enugu and Ebonyi States. Lessons for nhancing povrty alleviation programmes. In T.A. Olowu (eds). Agricultural extension and poverty alleviation in Nigeria. Proceedings of the $6^{\text {th }}$ Annual National Conference of the Agricultural Extension Society of Nigeria. Pp11

NPOC (2006). National Population Census. National Population Commission, Abuja, Nigeria.

Olaf Erenstein, Frederic Lançon, S.O. Akande, S.O. Titilola, G. Akpokodje and O.O. Ogundele (2003). The Nigerian Rice Economy In A Competitive World: Constraints, Opportunities And Strategic Choices. Rice production systems in Nigeria: A survey. West Africa Rice Development Association (WARDA) Abidjan, Côte d'Ivoire

Rahman, S.A., and J.I. Usman (2004). Comparative analysis of women's participation in agricultural production in Northern and Southern Kaduna State, Nigeria. Mobilizing investors for sustainable agricultural research, development and production in Nigeria. Proceedings of the $38^{\text {th }}$ Annual Conference of the Agricultural Society of Nigeria. Pp105-108

Rahman, S.A., J. Gabriel, and N.D. Marcus (2004). Gender differentials in labour contribution and productivity in farm production. Empirical evidence from Kaduna State of Nigeria. Paper presented at the National Conference on Family at makurdi, Nigeria. $1^{\text {st }}-5^{\text {th }}$ March 2004.

Rahman, S.A. (2008). Women's Involvement in Agriculture in Northern and Southern Kaduna State, Nigeria. Journal of Gender Studies, Volume 17, Issue1, pp1726

Singh, B. N., Fagade, S., Ukwungwu, M. N., William, C., Jagtap, S. S., Oladimeji, O., Efisue, A., and Okhidievbie, O. 1997. Rice growing environments and biophysical constraints in different agroecological zones of Nigeria. Met.J.2 1, 35-44.

UNDP (2005). State of Food Insecurity in the World. United Nations, FAO

World Bank (1996). Nigeria: Poverty in the midst of plenty The challenge of growth with inclusion. World Bank Report No. 14733-UNI

World Bank (2007). Human Development Report for Nigeria (HDR). November, 2007 